\title{
Aesthetics Value and Characters Education on Serat Kridhasmara Made by RM. Ngabehi Wangsa Sarsana
}

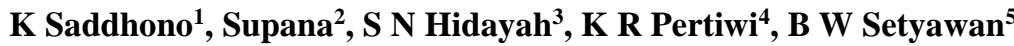 \\ $\left\{{ }^{1}\right.$ kundharu.uns@gmail.com, ${ }^{2}$ supana_77@yahoo.com, ${ }^{3}$ saadatun46@gmail.com, \\ ${ }^{4}$ kusumarp12@gmail.com.5bagusws93@gmail.com\} \\ 1,2,3,4,5 Universitas Sebelas Maret Surakarta, Indonesia
}

\begin{abstract}
The aims of this research are to describe and to explain about the aesthetics value and character education through Pakubuwono X figure on Serat Kridhasmara written by RM Ngabehi Wangsa Sarsana and its relevance as a learning material subject Tembang Jawa at SMP. The primary data source of this research is Serat Kridhasmara catalogue number P.B.C 103 from Museum Sonobudoyo, Yogyakarta. This work tells about the journey and love story between Pakubuwono X and his second wife, Kanjeng Ratu Hemas. Secondary data sources are taken from some documents such as book and some other articles which are used as reference in this research. This research is qualitative descriptive research. The data is analyzed by using content analysis. After analyzing the data, it is found that Serat Kridhasmara written by RM Ngabehi Wangsa Sarsana contains not only aesthetics values in love story of Pakubuwono $\mathrm{X}$ and his wife, but also contains the leadership values from Pakubuwono $\mathrm{X}$ figure which is useful in learning process on subject Tembang Macapat in Junior High School. This research concludes that Serat Kridhasmara can be used as an alternative of Tembang Macapat learning materials at SMP.
\end{abstract}

Keywords: Aesthetics Values, Characters Education, Serat Kridhasmara, Learning Material

\section{INTRODUCTION}

Indonesia is a nation that has wide variety of ethnics. The varieties of ethnic groups signify the greatness of Indonesia. The heritages from the ancestors which can be enjoyed and seen until now are candi (temple), prasasti (inscription stone), and other historical heritages[1]. One of which is the historical manuscripts that are kept with great care until now. A manuscript is written ideas that contain the various expression of thoughts and deep feelings about the life of people at a time. Robson [2] states that a manuscript is a literary work in the form of handbook and they are used to takes notes of important things. A manuscript contains the life teachings written by the ancestors. These teachings are beneficial if they are applied at a present. This research proves that tembang macapat, from its early existence in XIV century BC, can be applied in social life such as entertainment, aesthetics, education, traditional performances, means of correspondence, humming mate, a spell against bad omens, upacara temu manten Jawa (Javanese wedding ceremony), upacara pangestu, and as life philosophy[3]. 
Besides life teachings, a manuscript also contains literature that has a beauty or aesthetics. The presence of literature as part of the expression of society can manifest the phenomenon of life in institutional work [4]. Aesthetics or stylistics is a study in the use of language and generally related to literature. Ethymologically, the word aesthetic derives from Greek aistheta that means sensitivity or things perceived by senses. Historically, aesthetic is a branch of philosophy that means beauty. According to Marni [5] beautiful is a designation that people give to certain characteristics for an objects that arouse a certain pleasure within human which are called aesthetic. As stated by Ratna [6] that an aesthetic quality arouses life enthusiasm, love, loyalty and jealousy including intellectual spirit and struggle. The language aspect in the literature holds a very important role. It is not only related to the fact that the existence of a literature is determined by the language as a means of its presence, but also the fact that language is used to attain the effect of beauty [7]. Everything that is intended to be conveyed through literary works must first be understood by the use of language that functions as the "basic material" of writing. However, language can also be dealt with and created so that what is conveyed becomes more interesting. The presence of creativity is very important in the expression of literary works, thus called a creative works. A manuscript is one of literary works inherited from the ancestors that is called a creative literary work.

Language aesthetics are also contained in Javanese manuscript entitled Serat Krisdhasmara by Raden Mas Ngabehi Wangsasarsana which will be referred to with its abbreviation SK in this research. SK by Raden Mas Ngabehi Wangsasarsana tells about the love story of Pakubuwana X (B.R. M. G Malikul Kusno). At that time, he felt in love with a woman who eventually became his wife, Kanjeng Ratu Mas (B. R. A Mursudarinah). This manuscript also tells about the attitude or behavior of people who are in love, as experienced by Pakubuwana $\mathrm{X}$. Beside that this manuscript is interesting to be read, this manuscrpt also contains the aesthetic in each of pupuh. This makes the manuscript to be aesthetically superb. The aesthetic value of this manuscript is very interesting to be studied.

\section{RESEARCH METHOD}

The understanding gained from cultural research does not come by itself or expressed directly by the cultural reality but still needs to be reflected, intrepeted, and reconstructed [8]. This research uses descriptive qualitative method to reveal the various qualitative informations descriptions being studied to describe the wangsalan (metaphor) esthetic value of SK manuscript in detail and intact. Soejono [9] states that descriptive research is limited in portraying what happens at the present time and only on portraying stage. In line with this view, Rakhmat [10] who states that descriptive research aims to explain a situation or a events that applies. The source of data is Serat Kridhasmara by Raden Mas Ngabehi Wangsasarsana. Technique data collection used literature reviewing, namely data collection from the written sources by the researchers in order to obtain data along with lingual and literary context and teachings to be analyzed

\section{RESULT AND DISCUSSION}

\subsection{Serat Kridhasmara as a Local Heritage in Javanese Literature}

Serat Kridhasmara manuscript is written by poet Raden Mas Ngabehi Wangsasarsana. Every poet has their own particular way in using language. The pattern and the language characteristics which are used will signify the differences from one poet to another. The use of 
language with a particular pattern and characteristics will also signify the originality from every poet's minds on a certain matter [11]. This particularity in using languaga is shown by Raden Mas Ngabehi Wangsarsana in his SK manuscript. SK manuscript by Raden Mas Ngabehi Wangsasarsana is a Javanese manuscript in form of macapat song consisting of 7 pupuh, each of which has different sub-titles. There are 39 pages in SK manuscript with the consistent writing of thr number of verses. The third subtitle namely the third subtitles, Pamiluta, which is written in Pocung songs has a unique writing. In this subtitle, the writer uses a wangsalan (metaphor) which makes the text has a high aesthetic value.

Aesthetic is the beauty of Javanese literary works, especially macapat songs formed in several ways and supported by poetry or sound games called purwakanthi[12]. There are three types of purwakanthi in Javanese such as purwakanthi guru-swara, purwakanthi guru-sastra and purwakanthi basa. In addition, the beauty of Javanese language is supported by the choice of words and the use of words or group of words, such as like tembung garba (chaff garba) and the use of lelewaning basa (basic female use) or language style. One aesthetic aspect in a Javanese manuscript is a wangsalan (metaphor). Wangsalan (metaphor) is words similar with cangkriman (guessing games) in which its meaning must be guess and its answer is lied implicitly in the question given [13].

One example of wangsalan (metaphor) contained in SK manuscript is found in Pocung's pupuh at the first: Tanpa uwus yèn cinandra warnanipun / Sang Kusuma Rara / kolik priya tuhu luwih / siti rêngka pantês dipunêla-êla //. The wangsalan is "kolik priya tuhu luwih, siti rêngka pantês dipunêla-êla" = kolik priya is men's colic called tuhu, and siti rêngka is splitted ground called nêla (dipunêla-êla). The wangsalan (metaphor) shown above beautifies the song. So, if someone reads the manuscript, he/she will think about the meaning from the string of words arranged by the SK writer.

\subsection{Aesthetic Value and Wangsalan in Serat Kridhasmara}

Wangsalan (metaphor) is one of the aestehtics that exist in both prose or poems. According to W. J.S Poerwadarminta [14] Wangsalan is kn.-so) "tetemboengan ing oekara sing disamoen saemper tjangkriman, dJawabe (batangane) kaseboet ing oekara tjandake moeng ditjangking wandane bae, oep.roning mlinjo $(=s 0)$ sampoen sajah njoewoen ngaso (=nga-so)". Translated into: wangsalan (metaphor) is words which disguised in sentences, similiar with riddle, and the answer lays within the next sentence but only a syllabe that is carried in it, sometimes even just part of the syllable.

In SK manuscript especially in pupuh pocang, there can be found many wangsalan that contains answer or wangsulan disguised as riddle or guessing games that appears in the form of normal clause or in thw form of song[15]. The wangsalan can be seen below:

1. Tanpa uwus yèn cinandra warnanipun / Sang Kusuma Rara / kolik priya tuhu luwih / siti rêngka pantês dipunêla-êla //

The wangsalan is: "kolik priya tuhu luwih, siti rêngka pantês dipunêla-êla" = kolik priya is a male colic called tuhu, and siti rêngka is a split ground called nela (dipunêla-êla).

2. Tunggak pantun jalma lantaraning sêmu/lamun ngulatana / kêbo Bangka wining guling / kang apindha warnanira kusumendra //

The wangsalan: "tunggak pantun jalma lantaraning sêmu, lamun ngulatana" = jalma lantaraning sêmu called ulat, in this case written into ngulatana.

3. Kukus lêbu ron aking lêsah kismèku / lamun adhawuha / tangkil karang kutha aji / anjajaha nadyan luwih sèwu praja // 
The wangsalan is: "kukus lêbu ron aking lesah kismèku, tangkil karang kutha aji anjajaha nadyan luwih sèwu praja" = kukus lêbu called ground or kisma but written into kismèku and tangkil karang is called genjah but written into anjajaha.

4. Dewa Prabu basa kawêntaring têmbung / ngindra janaloka / mangsa wontêna kang sami / [11] panubiru amba puruntoh sayuta //

The wangsalan is "Dewa Prabu basa kawêntar ing têmbung" = basa kawêntar is called spoken language like word or têmbung.

5. Kipul gunung manawi wontêna iku / bulus mawa katga / mêmirip warni sakêdhik / rasa madu yêkti kaot manisira //

The wangsalan is "kimpul gunung manawi wontêna iku, bulus mawa katga, rasa madu yêkti kaot manisira" = kimpul gunung called tales which are round like round turle or bulus mawa katga. The taste of honey is sweet

6. Plimping têmbung maswagêng kaliha yèku/mung pasêmonira/sumèh prasaja sêmuning / tèrong dhèmpèl tur langkung bêkti ring garwa //

The wangsalan is "plimping têmbung maswagêng kaliha yèku, mung pasêmonira, sumèh prasaja sêmuning” = plimping têmbung is also called waswa or utterances, written into maswagêng. Sumèh is called èsêm or smile and is written into sêmuning.

7. Gudhe sulur roning mlijo13 suku jukung / prigêl solahira / mêrang lamawah ing dami / yèn micara patitis tur parikrama //

The wangsalan is "roning mlinjo suku jukung, prigel solahira, mêrang lamawah ing dami" = roning mlinjo or melinjo leaf called so, but written into solahira, mêrang is a rice stalk and the leaves are called damèn and it is written into dami.

8. Mêndhung limut eman-eman dhuh Gustiku / miranguning nala / lamun sandeya kinanthi / saron bumbung cacêngklungên ngarsa-arsa //

The wangsalan is "saron bumbung cacêngklungên ngarsa-arsa" = saron bumbung is called angklung but written into cacêngklungên.

9. Patrêm sawung wêlut wana jayèng ranu / pamuji kawula / baya nuntêna kapanggih / gambang kawat mupung 14 nêdhêng wancinira //

The wangsalan is "patrêm sawung wêlut wana jayèng ranu, pamuji kawula, baya nuntêna kapanggih, gambang kawat mumpung nêdhêng wancinira" = wêlut wana jayèng ranu is called baya or crocodile, gambang kawat is called pot written into wancinira.

10. Gayung sumur suling kaga timun agung / amban sawang mangka / Na[12]ta Radyan Dwarawati / pantês lamun dadya rowang awibawa //

The wangsalan is "gayung sumur suling kaga timun agung, amban sawang mangka" = gayung sumur is called dipper or bucket written into amban.

11. Barkutut gung putêr putih wismèng panggung / dhuh muga Bandara / candra matanggaping warsi / adawosa musthikaning Surakarta //

The wangsalan is "barkutut gung putêr putih wismèng panggung" = barkutut gung is called dara or barbary dove.

12. Jayèng pupuh pan tinata kapriagung / tugul purantara / satriya sangkaning wukir / dènbang-èbang dadya pandam pangauban //

The wangsalan is "jayèng pupuh pan tinata kapriagung, tunggul purantara" = jayèng pupuh or unggul (winning in war), is also called superior written into tunggul.

13. Kêthèk jamus kawiweka amrih runtut / garwa putranata / ciri raga manggis kuning / mung cacade sagêt ngecani tyasama //

The wangsalan is "ciri raga manggis kuning, mung cacade sagêt ngecani tyasama" = yellow mangosteen is called kaleca written into ngecani. 
14. Kêndhil agung kêmirêng gandha arum / garwa miwah kadang / pinrih asih angrêsêpi / kutha boma sala mapinardi trêsna //

The wangsalan is "kêndhil agung kêmirêng gandha arum, garwa miwah kadang, Kutha Boma Sala mapinardi trêsna” = kêndhil agung is called boiler pot written into kadang, Kutha Boma is called trajutrisna written into trêsna.

15. Guwa pandung sambayang jalma nênuwun / nambahana drajat / kaluhuran narapati / witing lakon jêjêring ngawiryèng praja //

The wangsalan is "guwa pandung sambayang jalma nênuwun" = guwa pandung is called suwun written into nênuwun.

16. Dhasar sampun gusti kawistarèng [13] sêmu / mênêting kang cahya / nandur pari tanpa warih / wèh rarasing raga apa wus cinêtha //

The wangsalan is "nandur pari tanpa warih, wèh rarasing raga apa wus cinêtha" = warih is called wè (water) written into as wèh.

17. Ngalêm patut sarot16 pada kisma mawut / pan dadya sènêtan / nurbuwat Rasullolahi / Salu alaihi salam rasanira //

The wangsalan is "ngalêm patut sorot pada kisma mawut, pan dadya sènêtan, nurbuwat Rasullolahi, Salu alaihi salam rasanira" = sorot (ray) is called nur or light and written into nurbuwat.

18. Ingkang sampun / cinipta ing lokilmakpul/dhadha jaja sèta / ugi pitulung Hyang Widdhi / tuduh nyata yèku nama Gusti amba //

The wangsalan "dhadha jaja seta" = dhadha is called jaja or dada (chest).

19. Murwèng tuwuh supadya panardyèng lulut / darapon karasan / rina rêmih sapakolih / nahên suka tan pêgat mêsu noraga //

The wangsalan is "murwèng tuwuh supadya panardyèng lulut, darapon karasan, nahên suka tan pêgat mêsu noraga" = panardyèng is called raras but written into karasan, nahên is called nêsu or happiness but written into mêsu.

Out of 20 stanzas of pupuh pocung in SK manuscript, it found that there are 19 verses which contain wangsalan. Wangsalan is useful for beautifying the songs in SK so that it has high aesthetic value. In addition to beautifying the songs, wangsalan also makes the reader to think of the real meaning of the words. The meaning from each words is a wangsalan that has aesthetic meaning.

\section{CONCLUSIONS}

From the description of the SK manuscript in pupuh pocung above, it can be concluded that in each verses there is wangsalan to beautify the songs. One example is in the last stanza "murwèng tuwuh supadya panardyèng lulut, darapon karasan, nahên suka tan pêgat mêsu noraga” = panardyèng lulut called raras written into karasan, nahên called nesu or holding back the happiness and written into mêsu. There are 19 song verses that have wangsalan and wangsalan is very useful for beautifying the songs.

\section{REFERENCES}

[1] A. A. Puspita, A. Sachari, and A. B. Sriwarno, "Knowledge from Javanese Cultural Heritage: How They Manage and Sustain Teak Wood," Cultura, vol. 15, no. 1, pp. 2348, 2018.

[2] S. O. Robson, Prinsip-Prinsip Filologi Indonesia, terj. Kentjanawati Gunawan. Jakarta: 
Pusat Pembinaan dan Pengembangan Bahasa, 1994.

[3] P. Santosa, "Fungsi Sosial Kemasyarakatan Tembang Macapat (Community Social Funtions of Macapat)," Widyaparwa, vol. 44, no. 2, pp. 85-97, 2016.

[4] D. P. Prabowo, "Sastra Propaganda: Sebuah Studi Kasus Tembang Macapat pada Era Orde Baru di KMD Kandha Raharja,” Widyaparwa, vol. 40, no. 2, pp. 1-12, 2012.

[5] T. Marni, "Nilai-nilai Estetika Bahasa Melayu Dialek Kampar." Dinas Kebudayaan dan Pariwisata Propinsi Riau, Pekanbaru, 2009.

[6] N. K. Ratna, Sastra dan Cultural Studies: Representasi Fiksi dan Fakta. Yogyakarta: Pustaka Pelajar, 2007.

[7] C. M. Mueller, "Initial Acquisition of Tense-aspect Morphology in an Artificial Language," Second Lang. Res., vol. 34, no. 4, pp. 517-538, 2018.

[8] S. Endraswara, Metode Penelitian Kebudayaan. Yogyakarta: Gadjah Mada Press, 2006.

[9] A. Soejono and H. Abdurrahman, Metode Penelitian Suatu Pemikiran dan Penerapan. Jakarta: PT Rineka Cipta, 1999.

[10] B. W. Setyawan, K. Saddhono, and A. Rakhmawati, "Potret Kondisi Sosial Masyarakat Jawa dalam Naskah Ketoprak Klasik Gaya Surakarta,” Aksara, vol. 30, no. 2, pp. 205 220, 2018.

[11] R. K. Ibrahim and L. A. K. Hussein, "A Critical Stylistic Analysis of the Ideological Positioning in Some Selected Poems by John Donne," J. Coll. Lang., no. 37, pp. 1-16, 2018.

[12] S. Nugroho, "The Aesthetics Effect of Surakarta-Style Pakeliran on East Javanese Pakeliran," Harmon. J. Arts Res. Educ., vol. 18, no. 2, pp. 153-161, 2018.

[13] Padmosoekotjo, Ngrengrengan Kasusastran Jawa II. Yogyakarta: Hien Hoo Sing, 1956.

[14] W. J. S. Poerwadarminta, Baoesastra Djawa. Batavia: JB Wolters, 1939.

[15] M. D. Barnett, K. B. Sligar, and C. D. C. Wang, "Religious Affiliation, Religiosity, Gender, and Rape Myth Acceptance: Feminist Theory and Rape Culture," J. Interpers. Violence, vol. 33, no. 8, pp. 1219-1235, 2018. 